Bangladesh J. Plant Taxon. 13(2): 73-82, 2006 (December)

\title{
EVALUATION OF RAPD MARKERS FOR TAXONOMIC RELATIONSHIPS IN SOME AQUATIC SPECIES OF UTRICULARIA L. (LENTIBULARIACEAE)
}

\author{
MOHAMMAD OLIUR RAHMAN ${ }^{1}$ \\ Bangladesh National Herbarium, Chiriakhana Road, Mirpur-1, \\ Dhaka 1216, Bangladesh
}

Key words: Aquatic Utricularia, Genetic affinity, Neighbour Joining, RAPD, Systematic relationships, UPGMA

\begin{abstract}
Random amplified polymorphic DNA (RAPD) markers were used to assess relationship across nine aquatic species of Utricularia. The highest numbers of RAPD bands were detected in Utricularia bremii and $U$. intermedia. The highest genetic similarity was observed between $U$. australis and $U$. dimorphantha; between $U$. australis and $U$. vulgaris; and between $U$. dimorphantha and $U$. macrorhiza indicating that these species are closely related. Unweighted pair group method with arithmetic mean (UPGMA) analysis based on the RAPD profile in aquatic Utricularia resolved the taxa into three clusters: the first cluster included $U$. aurea, $U$. australis, $U$. dimorphantha, $U$. macrorhiza and $U$. vulgaris; the second cluster constituted from U. bremii and U. gibba while $U$. intermedia formed the third cluster with $U$. minor. The Neighbour Joining (NJ) tree showed that aquatic species could be placed in two main groups and the results obtained from the NJ analysis were coherent with that of the UPGMA clustering method. The molecular findings revealed from this study support the systematic relationships in Utricularia inferred from morphological investigations.
\end{abstract}

\section{Introduction}

The development of random amplified polymorphic DNA (RAPD) markers generated by polymerase chain reaction (PCR) using arbitrary primers has resulted in alternative molecular markers for the detection of nuclear DNA polymorphism (Williams et al. 1990). RAPD markers detect nucleotide sequence polymorphisms, providing fingerprints for individuals and populations. These sequence polymorphisms may arise due to changes in the random priming sites on the template or because of insertions or deletions in the DNA downstream of the site, changing the size of the amplified fragment. RAPD method employs a lower annealing temperature during amplification (35-39 ${ }^{\circ} \mathrm{C}$ compared to the usual $50-55^{\circ} \mathrm{C}$ ) because of using random primers (Bowditch et al. 1994). The resulting PCR products from RAPD analysis are electrophorized on 1.5$2.0 \%$ agarose gel and stained with ethidium bromide. Sometimes polyacrylamide gel and silver staining are also used. Huff and Bara (1993) found silver-stained RAPD markers more reliable than RAPD analysis using agarose gel and ethidium bromide staining. However, the agarose gel with ethidium bromide staining were used successfully by Sweeney and Danneberger (1995). Electrophoresis of a set of products translated from different DNA regions chosen by the primer produces a series of bands in this technique (Schierwater 1995).

\footnotetext{
${ }^{1}$ Email : oliurrahman@yahoo.com
} 
The RAPD technique has many advantages such as detection of polymorphism, relatively inexpensive, fast, and reliable. In addition, it utilizes primers of arbitrary sequences which may be used for different species and does not require previous knowledge of DNA sequence. RAPD markers have found application in many fields including DNA fingerprinting (Caetano-Anollés et al. 1991, Micheli et al. 1994), assessment of genetic diversity (Bolaric et al. 2005, Bodo Slotta and Porter 2006), cultivar identification (Koller et al. 1993, Al-Khalifah and Askari 2003), estimation of population genetic parameters (Oiki et al. 2001, Sales et al. 2001), hybridization (Caraway et al. 2001, Triest 2001), systematics (Díaz Lifante and Aguinagalde 1996, Vilatersana et al. 2005), phylogeny reconstruction (Rath et al. 1998, Ahmed et al. 2005) and genome mapping (Stockinger et al. 1996, Krutovskii et al. 1998). RAPD markers have been used in different group of plants. These markers have also been applied successfully in many aquatic plants. San Martín et al. (2003) applied these markers for detecting genetic variation in Aldrovanda vesiculosa. Madeira et al. (1997) determined phenetic relationships among accessions of Hydrilla verticillata. Waycott (1995) assessed genetic variation in seagrass Posidonia australis employing RAPD and allozyme analyses.

Utricularia, a member of the family Lentibulariaceae, encompasses 214 species and is distributed throughout the world with the largest number of species in tropical and central America (Taylor 1989). Many important contributions were made on Utricularia based on morphology (Taylor 1989, Crow 1992), cytology (Casper and Manitz 1975, Pogan et al. 1990) and palynology (Huynh 1968, Sohma 1975). However, molecular techniques have not been widely used in this genus to evaluate genetic variation and to infer systematic relationships except a few investigations (Müller et al. 2002, Rahman and Kondo 2003). RAPD markers have never been tested in this important carnivorous genus. The present study offers a methodological approach using RAPDs to investigate partitioning of variation and taxonomic relationships among nine aquatic species of Utricularia. This investigation examines the suitability of RAPDs as a tool for identifying Utricularia species and detecting genetic variability among the species.

\section{Materials and Methods}

Plant materials: The species of Utricularia employed in this study are listed in Table 1. The species were grown in both in vitro and in vivo cultures at the Laboratory of Plant Chromosome and Gene Stock, Graduate School of Science, Hiroshima University, Japan. In order to grow the species in vitro culture B5 medium was used (Gamborg et al. 1968).

Isolation of DNA: Total DNA was isolated from the leaf tissue ranging from 1.0g to 1.8g using CTAB (Cetyl trimethyl ammonium bromide) method. See Rahman and Kondo (2003) for detailed protocol for DNA extraction. The isolated DNA was dissolved in TE buffer and stored at $-20^{\circ} \mathrm{C}$. 
RAPD amplification : RAPD primers were purchased from Operon Technology. The following oligonucleotide primers were examined for RAPD analysis which provided good amplified products: OPA1, OPA2, OPA3, OPA4, OPA7, OPA9, OPA13, OPB1, OPB4, OPB5, OPB6, OPB8, OPB11, OPB15, OPB17 and OPB18. Each PCR included 20ng of DNA, 10 pmol primer, $1 \mu \mathrm{l} 10 \mathrm{X}$ Ex Taq buffer, $1 \mu \mathrm{l}$ of dNTP mixture, $0.05 \mu l$ Taq polymerase enzyme, and sterile, deionised water up to final volume of $12 \mu \mathrm{l}$. The reaction mixture was overlaid with $30 \mu \mathrm{l}$ mineral oil. PCR reaction was performed in a PTC-100 thermal cycler as per following temperature profile: $1 \mathrm{~min}$ at $94^{\circ} \mathrm{C}, 1 \mathrm{~min}$ at $35^{\circ} \mathrm{C}$ and 2 min at $72^{\circ} \mathrm{C}$ followed by 45 cycles. A final 5 min extension at $72^{\circ} \mathrm{C}$ ensured full extension of all amplified fragments.

Table 1. List of the aquatic species of Utricularia employed in the present study.

\begin{tabular}{lccl}
\hline Name of the species & $\begin{array}{c}\text { Cultivation } \\
\text { procedure }\end{array}$ & $\begin{array}{c}\text { Amount } \\
\text { of leaf (g) }\end{array}$ & Distribution* \\
\hline U. aurea Lour. & In vitro & 1.2 & NAS, TAS, MAL, ANZ \\
U. australis R. Br. & In vivo & 1.5 & EUA, NAS, AFR, TAS, MAL, ANZ \\
U. bremii Heer ex. Kölliker & In vitro & 1.8 & EUA \\
U. dimorphantha Makino & In vivo & 1.5 & NAS \\
U. gibba L. & In vitro & 1.4 & NAM, CAM, SAM, EUA, NAS, \\
& & & AFR, TAS, MAL, ANZ \\
U. intermedia Hayne & In vivo & 1.0 & NAM, EUA, NAS \\
U. macrorhiza LeConte & In vivo & 1.3 & NAM, CAM, NAS \\
U. minor L. & In vivo & 1.2 & NAM, EUA, NAS, TAS, MAL \\
U. vulgaris L. & In vivo & 1.1 & EUA, NAS \\
\hline
\end{tabular}

* After Taylor (1989)

CAM: Central America from Mexico to Panama, including all the islands in the Caribbean from the Bahamas southwards to Trinidad; SAM: South America from Colombia to Argentina and Chile, including the Galapagos Islands; NAM: North America, including the whole of the United States, Canada and Greenland. NAS: North Asia, including USSR east to the Urals, China, Mongolia, Korea and Japan; TAS: Tropical Asia from Pakistan to Indo-China; MAL: Malesia from the Malay peninsula to New Guinea, including the islands of Guam and Palau; ANZ: Australia, New Zealand and New Caledonia; EUA: Europe, North Africa, and the Middle eastern countries to Afghanistan; AFR: Africa, south of Sahara with Madagascar and the Mascarene Islands.

Gel electrophoresis: Amplified products were mixed with bromophenol dye and were analyzed on $1.5 \%$ agarose gel following ethidium bromide staining for 30 minutes. The bands were visualized under ultra-violet radiation and photographed.

Data analysis: RAPD bands were recorded in a binary data matrix scored as presence (1) or absence (0). Simple Matching coefficient was used for measuring genetic similarity among the species analyzed. UPGMA (unweighted pair group method with arithmetic mean) tree was generated by clustering the similarity data and SAHN (sequential, agglomerative hierarchical and nested clustering) method. Dist coefficient was employed 
to know the dissimilarity level between the species examined. A Neighbour Joining (NJ) tree was constructed based on Jukes and Cantor (1969) distance coefficient. NTSYS-pc package, version 2.1 was used for all analyses (Rohlf 2000).

\section{Results and Discussion}

RAPD fingerprints and genetic variation: RAPD markers generated reproducible fingerprints across the aquatic species tested. Some RAPD primers were ignored because of presenting artifacts. The electrophoretic pattern of PCR amplified RAPD fingerprints generated by the primer OPB15 is shown in Figure 1. The highest number of RAPD bands was observed in Utricularia intermedia followed by $U$. bremii. In contrast, $U$. vulgaris showed the least number of bands.

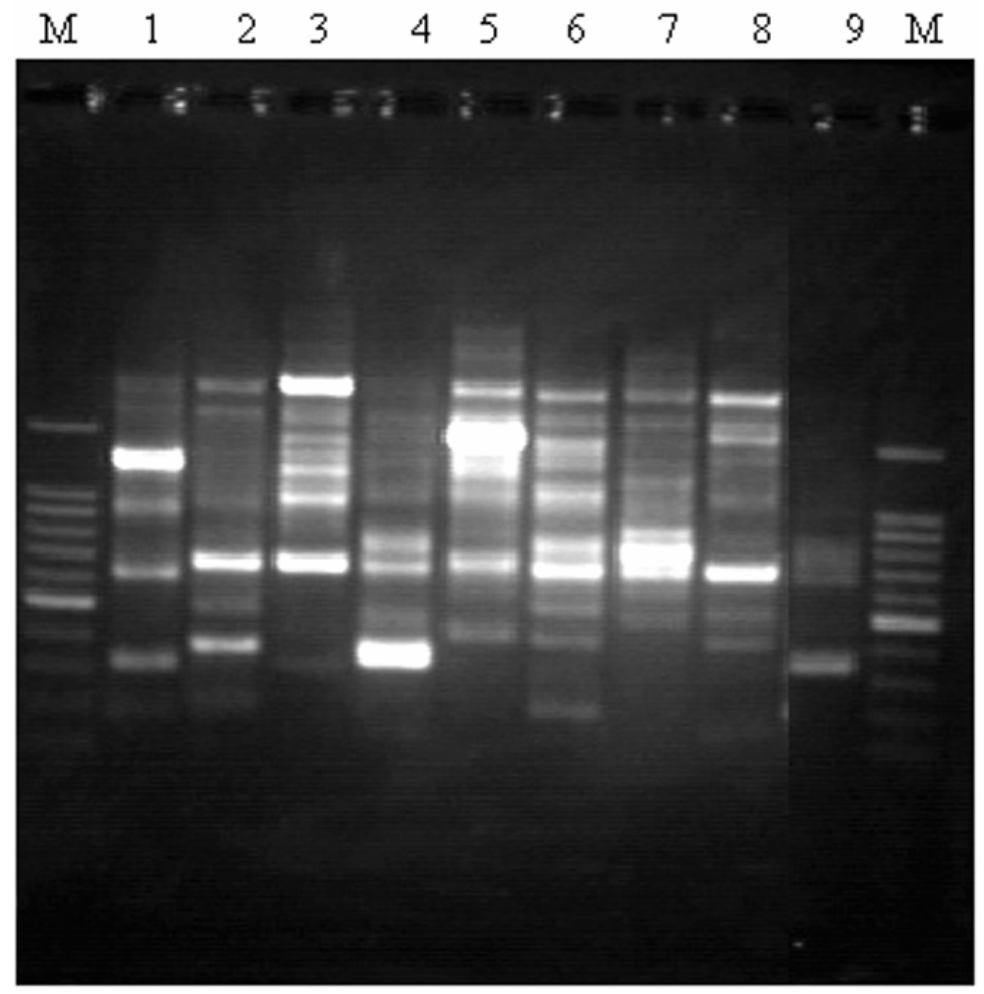

Fig. 1. Electrophoretic pattern of PCR amplified RAPD banding profile on 1.5\% agarose gel for aquatic Utricularia species with the primer OPB15. M. Molecular size marker (100 bp), 1. U. aurea, 2. U. australis, 3. U. bremii, 4. U. dimorphantha, 5. U. gibba, 6. U. intermedia, 7. U. macrorhiza, 8. U. minor and 9. U. vulgaris.

Across the aquatic species of Utricularia, the highest genetic similarity (9.37) has been found between $U$. australis and $U$. dimorphantha; between $U$. australis and $U$. 
vulgaris; and between $U$. dimorphantha and $U$. macrorhiza indicating that these species are very closely related (Table 2). Utricularia bremii was found close to U. gibba showing a high genetic affinity (8.75). On the other hand, the highest dissimilarity (7.07) was detected between $U$. aurea and $U$. bremii; $U$. aurea and $U$. intermedia; $U$. bremii and $U$. dimorphantha; and U. dimorphantha and U. intermedia.

Table 2. Similarity matrix among the aquatic species of Utricularia studied by RAPD markers using Simple Matching coefficient.

\begin{tabular}{|c|c|c|c|c|c|c|c|c|c|}
\hline Species & $\begin{array}{c}U . \\
\text { aurea }\end{array}$ & $\begin{array}{c}U . \\
\text { australis }\end{array}$ & $\begin{array}{c}U . \\
\text { bremii }\end{array}$ & $\begin{array}{c}U . \\
\text { dimorphantha }\end{array}$ & $\begin{array}{c}U . \\
g i b b a\end{array}$ & $\begin{array}{c}U . \\
\text { intermedia }\end{array}$ & $\begin{array}{c}U . \\
\text { macrorhiza }\end{array}$ & $\begin{array}{c}U . \\
\text { minor }\end{array}$ & $\begin{array}{c}U . \\
\text { vulgaris }\end{array}$ \\
\hline U. aurea & 1 & & & & & & & & \\
\hline U. australis & 6.87 & 1 & & & & & & & \\
\hline U. bremii & 5.00 & 5.62 & 1 & & & & & & \\
\hline U. dimorphantha & 6.25 & 9.37 & 5.00 & 1 & & & & & \\
\hline U. gibba & 6.25 & 6.87 & 8.75 & 6.25 & 1 & & & & \\
\hline U. intermedia & 5.00 & 5.62 & 5.00 & 5.00 & 6.25 & 1 & & & \\
\hline U. macrorhiza & 6.87 & 8.75 & 5.62 & 9.37 & 6.87 & 5.62 & 1 & & \\
\hline U. minor & 6.25 & 6.87 & 5.00 & 6.25 & 6.25 & 7.50 & 6.87 & 1 & \\
\hline U. vulgaris & 7.50 & 9.37 & 6.25 & 8.75 & 7.50 & 6.25 & 8.12 & 7.50 & 1 \\
\hline
\end{tabular}

Taxonomic relationships: For aquatic species of Utricularia, dendrograms were constructed both from UPGMA and NJ analyses. UPGMA dendrogram in aquatic species based on Dist coefficient resulted in producing three clusters (Fig. 2). In the first cluster $U$. australis grouped with $U$. dimorphantha and $U$. macrorhiza was joined with this group in which $U$. vulgaris was joined, and morphologically, these species are closely related. Utricularia aurea was found sister to this group. The lowest dissimilarity (25\%) was obtained in this group between $U$. australis and $U$. dimorphantha indicating that they are very close to each other. The second cluster made from U. bremii and U. gibba was found as a sister group to the cluster having $U$. aurea, $U$. australis, $U$. dimorphantha, $U$. macrorhiza and $U$. vulgaris (Fig. 2). The third cluster consisted of Utricularia minor and $U$. intermedia and these two species were found far away from other aquatic species employed.

The NJ tree constructed on the basis of Jukes and Cantor coefficient revealed that aquatic species could be placed into two main groups: the first group possessed five species including $U$. aurea, $U$. australis, U. dimorphantha, U. macrorhiza and $U$. vulgaris and the second one consisted of four species, namely, U. bremii, U. gibba, $U$. intermedia and $U$. minor (Fig. 3). The second group contained two clusters where $U$. bremii and $U$. gibba formed one cluster and the second one was made by $U$. intermedia 
and U. minor. The NJ analysis showed the similar results with that of the UPGMA clustering method.

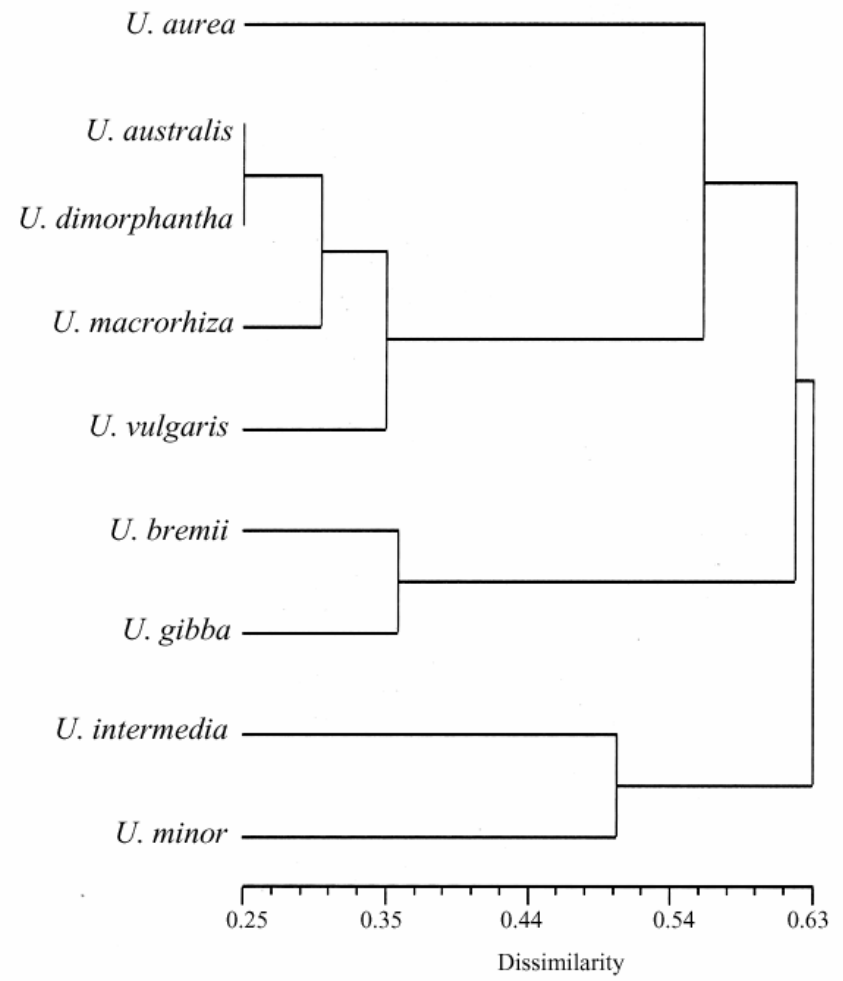

Fig. 2. Dendrogram showing relationships among aquatic Utricularia species based on UPGMA analysis generated by RAPD markers.

In recent years, several DNA markers were developed for genome analysis and have been found suitable in molecular systematic studies. The DNA markers commonly used in molecular studies include RFLP (Restriction fragment length polymorphism; Botstein et al. 1980), SSR (Simple sequence repeat; Tautz and Renz 1984), RAPD (Williams et al. 1990), ISSR (Inter simple sequence repeat; Zietkiewicz et al. 1994) and AFLP (Amplified fragment length polymorphism; Vos et al. 1995). Among these marker systems available RAPD is the most popular approach that has wide range of applications. Application of these markers in aquatic plants is quite evident (Piquot et al. 1996, Padgett et al. 1998, Madeira et al. 2000).

In the genus Utricularia, application of DNA markers is very limited. Recently, Rahman and Kondo (2003) applied ISSR markers in terrestrial Utricularia and found them useful for species delimitation. However, RAPD markers were not tested in this genus earlier. The present investigation revealed that RAPD markers are useful to 
characterize aquatic Utricularia species. The RAPD analyses in aquatic Utricularia showed that $U$. australis, $U$. dimorphantha, U. macrorhiza and $U$. vulgaris could be grouped together. In another study, these aquatic species of Utricularia were investigated by some other molecular markers, like ISSR, and $U$. australis was found very close to $U$. dimorphantha, while U. gibba was found near to U. bremii (M. Oliur Rahman, unpublished). The interspecific relationships in aquatic Utricularia based on RAPD

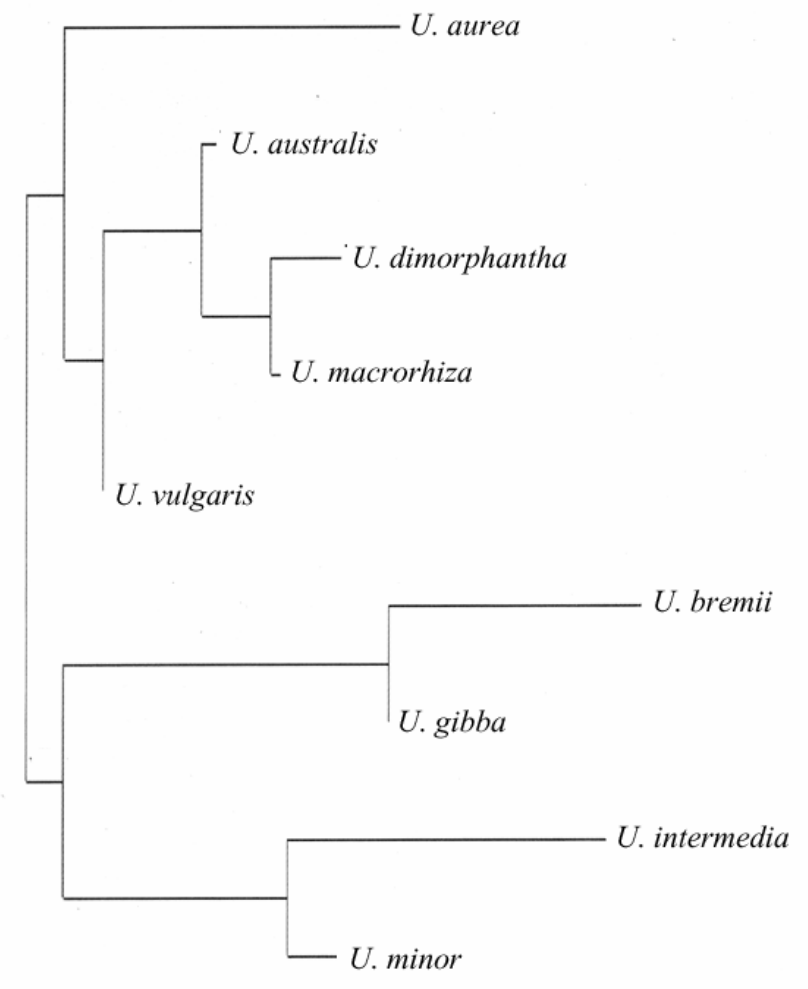

Fig. 3. Neighbour Joining tree for aquatic Utricularia species using Jukes and Cantor coefficient based on RAPD data.

analysis is in agreement with the results obtained from the previous study inferred from ISSR analysis. Morphologically, $U$. dimorphantha is allied to $U$. australis by having basifixed bracts, curved filaments, globose ovary, globose capsule and prismatic seeds. A close relationship was evident among $U$. australis, $U$. macrorhiza and $U$. vulgaris in the present study, which was concordant with their morphology. For instance, leaves of these species divided into two primary segments each of which pinnately divided and the secondary segments divided into further segments. These species showed dimorphic traps and the basal traps were ovoid (Taylor 1989). Cytologically, Utricularia australis and $U$. macrorhiza presented the same gametic number of chromosome (Casper and Manitz 
1975). Utricularia macrorhiza is also close to $U$. vulgaris in terms of somatic chromosome numbers (Löve 1954, 1982). The RAPD data revealed that $U$. minor was genetically closely related to $U$. intermedia. Some morphological characters such as ovate or ovate-deltoid bracts, subequal calyx lobes, curved filament and globose ovary placed these two species in the same line (Taylor 1989).

In conclusion, RAPD markers were found suitable to detect genetic variation and species relationships in aquatic Utricularia. In addition, the results obtained from RAPD analysis in Utricularia were in agreement with previous studies based on morphological, cytological and molecular approaches.

\section{Acknowledgements}

The author thanks Prof. Katsuhiko Kondo of the Laboratory of Plant Chromosome and Gene Stock, Hiroshima University, Japan for his cooperation during the course of this study. Thanks are also due to the Government of Japan for providing the author with Monbukagakusho scholarship for conducting Ph.D. research of which this communication is a part.

\section{References}

Ahmed, S.M., Verma, V., Qazi, P.H., Ganaie, M.M., Bakshi, S.K. and Qazi, G.N. 2005. Molecular phylogeny in Indian Tinospora species by DNA based molecular markers. Plant Syst. Evol. 256 (1-4): 75-87.

Al-Khalifah, N.S. and Askari, E. 2003. Molecular phylogeny of date palm (Phoenix dactylifera L.) cultivars from Saudi Arabia by DNA fingerprinting. Theor. Appl. Genet. 107: 1266-1270.

Bodo Slotta, T.A. and Porter, D.M. 2006. Genetic variation within and between Iliamna corei and I. remota (Malvaceae): implications for species delimitation. Bot. J. Linn. Soc. 151: 345-354.

Bolaric, S., Barth, S., Melchinger, A.E. and Posselt, U.K. 2005. Genetic diversity in European perennial ryegrass cultivars investigated with RAPD markers. Plant Breeding 124 (3): 257-262.

Botstein, D., White, R.L., Skolnick, M. and Davis, R.W. 1980. Construction of a genetic map in man using restriction fragment length polymorphism. Am. J. Hum. Genet. 32: 314-330.

Bowditch, B.M., Albright, D.G., Williams, J.K. and Braun, M.J. 1994. Use of randomly amplified polymorphic DNA markers in comparative genetic studies. Methods in Enzymology 224: 294-309.

Caraway, V., Carr, G.D. and Morden, C.W. 2001. Assessment of hybridization and introgression in lavacolonizing Hawaiian Dubautia (Asteraceae: Madiinae) using RAPD markers. Am. J. Bot. 88: 16881694.

Caetano-Anollés, G., Bassam, B.J. and Gresshoff, P.M. 1991. DNA amplification fingerprinting using very short arbitrary oligonucleotide primers. Biotechnology 9: 553-557.

Casper, S.J. and Manitz, H. 1975. Beitrage zur Taxonomie und Chorologie der mitteleuropäischer Utricularia-Arten, 2. Androsporogenese, chromosomenzahlen und pollenmorphologie. Feddes Repert. 86: 211-232.

Crow, G.E. 1992. The genus Utricularia (Lentibulariaceae) in Costa Rica. Brenesia 38: 1-18. 
Díaz Lifante, Z. and Aguinagalde, I. 1996. The use of random amplified polymorphic DNA (RAPD) markers for the study of taxonomic relationships among species of Asphodelus sect. Verinea (Asphodelaceae). Am. J. Bot. 83: 949-953.

Gamborg, O.L., Miller, R.A. and Ojima, K. 1968. Nutrient requirements of suspension cultures of soybean root cells. Exp. Cell Res. 50: 151-158.

Huff, D.R. and Bara, J.M. 1993. Determining genetic origins of aberrant progeny from apomictic Kentucky bluegrass using a combination of flow cytometry and silver stained RAPD markers. Theor. Appl. Genet. 87: 201-208.

Huynh, K.L. 1968. Etude de la Morphologie du pollen du genre Utricularia L. Pollen et Spores 10: 11-55.

Jukes, T.H. and Cantor, C.R. 1969. Evolution in protein molecules. In: H. N. Munro (ed.). Mammalian protein metabolism. Academic press. New York, pp. 21-23.

Koller, B., Lehmann, A., McDermott, J.M. and Gessler, C. 1993. Identification of apple cultivars using RAPD markers. Theor. Appl. Genet. 85: 901-904.

Krutovskii, K.V., Vollmer, S.S., Sorensen, F.C., Adams, W.T., Knapp, S.J. and Strauss, S.H. 1998. RAPD genome maps of Douglas-fir. J. Heredity 89: 197-205.

Löve, A. 1954. Cytotaxonomical evaluations of corresponding taxa. Vegetatio 5-6: 212-224.

Löve, A. 1982. In: IOPB chromosome number reports LXXX. Taxon 31: 324-368.

Madeira, P., Van, T., Steward, K. and Schnell, R. 1997. Random amplified polymorphic DNA analysis of the phenetic relationships among world-wide accessions of Hydrilla verticillata. Aquatic Botany 59: 217236.

Madeira, P.T., Jacono, C.C and Van, T.K. 2000. Monitoring Hydrilla Using Two RAPD Procedures and the Nonindigenous Aquatic Species Database. J. Aquat. Plant Manage. 38: 33-40.

Micheli, M.R., Bova, R., Pascale, E. and D’Ambrosio, E. 1994. Reproducible DNA fingerprinting with the random amplified polymorphic DNA (RAPD) method. Nucleic Acids Res. 22: 1921-1922.

Müller, K., Borsch, T., Legendre, L., Theisen, I. and Barthlott, W. 2002. Evolution of Carnivory in the Lentibulariaceae: considerations based on molecular, morphological, and physiological evidence. Proceedings of the $4^{\text {th }}$ International Carnivorous Plant Conference, Tokyo, Japan , pp. 63-73.

Oiki, W., Kawahara, T., Inoue, K., Ohara, M. and Maki, M. 2001. Random amplified polymorphic DNA (RAPD) variation among populations of the Insular endemic plant Campanula microdonta (Campanulaceae). Ann. Bot. 87: 661-667.

Padgett, D.J., Les, D.H. and Crow, G.E. 1998. Evidence for the hybrid origin of Nuphar x rubrodisca (Nymphaeaceae). Amer. J. Bot. 85:1468-1476

Piquot, Y., Saumitou-Laprade, P., Petit, D., Vernet, P. and Epplen, J.T. 1996. Gentopyic diversity revealed by allozymes and oligonucleotide DNA fingerprinting in French populations of the aquatic macrophyte Sparganium erectum. Mol. Ecol. 5: 251-258.

Pogan, E., Jankun, A. and Sawicka, Z. 1990. Further studies in chromosome numbers of Polish angiosperms. Part 22. Acta Biol. Cracov., Ser. Bot. 31: 1-17.

Rahman, M.O. and Kondo, K. 2003. Genetic diversity and species relationship of some terrestrial bladderwort (Utricularia L.) as revealed by inter simple sequence repeat (ISSR) markers. Acta Phytotaxon. Geobot. 54 (1): 49-57.

Rath, P., Rajaseger, G., Goh, C.J. and Kumar, P.P. 1998. Phylogenetic analysis of Dipterocarps using random amplified polymorphic DNA markers. Ann. Bot. 82: 61-65. 
Rohlf, F.J. 2000. NTSYSpc: Numerical taxonomy and multivariate analysis system, version 2.1. Exeter Software, Setauket, New York, USA.

Sales, E., Nebauer, S.G., Mus, M. and Segura, J. 2001. Population genetic study in the Balearic endemic plant species Digitalis minor (Scrophulariaceae) using RAPD markers. Am. J. Bot. 88: 1750-1759.

San Martín, A.P.M., Adamec, L., Suda, J., Med, T.H.M. and Helena Štorchová, H. 2003. Genetic variation within the endangered species Aldrovanda vesiculosa (Droseraceae) as revealed by RAPD analysis. Aquatic Botany 75 (2): 159-172.

Schierwater, B. 1995. Arbitrarily amplified DNA in systematics and phylogenetics. Electrophoresis 16: 16431647.

Sohma, K. 1975. Pollen morphology of the Japanese species of Utricularia L. and Pinguicula L. with notes on fossil pollen of Utricularia from Japan (1). Journ. Jap. Botany 50(6): 164-179.

Stockinger, E.J., Mulinix, C.A., Long, C.M., Brettin, T.S. and Lezzoni, A.F. 1996. A linkage map of sweet cherry based on RAPD analysis of a microspore-derived callus culture population. J. Heredity 87: 214218.

Sweeney, P.M. and Danneberger, T.K. 1995. RAPD characterization of Poa annua L. populations in golf course greens and fairways. Crop Science 36: 1676-1680.

Tautz, D. and Renz, M. 1984. Simple sequences are ubiquitous repetitive components of eukaryotic genomes. Nucleic Acids Res. 12: 4127-4138.

Taylor, P. 1989. The genus Utricularia - a taxonomic monograph. Kew Bulletin, Additional Series XIV: 1724. Her Majesty’s Stationery Office, London.

Triest, L. 2001. Hybridization in staminate and pistillate Salix alba and S. fragilis (Salicaceae): morphology versus RAPDs. Plant Syst. Evol. 226 (3-4): 143-154.

Vilatersana, R., Garnatje, T., Susanna, A. and Garcia-Jacas, N. 2005. Taxonomic problems in Carthamus (Asteraceae): RAPD markers and sectional classification. Bot. J. Linn. Soc. 147: 375-383.

Vos, P., Hogers, R., Bleeker, M., Reijans, M., van der Lee, T., Hornes, M., Frijters, A., Pot, J., Peleman, J., Kuiper, M. and Zabean, M. 1995. AFLP: a new technique for DNA fingerprinting. Nucleic Acids Res. 23: 4407-4414.

Waycott, M. 1995. Assessment of genetic variation and clonality in the seagrass Posidonia australis using RAPD and allozyme analysis. Mar. Ecol. Prog. Ser. 116: 289-295.

Williams, J.G.K., Kubelik, A.R., Livak, K.J., Rafalski, J.A. and Tingey, S.V. 1990. DNA polymorphisms amplified by arbitrary primers are useful as genetic markers. Nucleic Acids Res. 18: 6531-6535.

Zietkiewicz, E., Rafalski, A. and Labuda, D. 1994. Genome fingerprinting by simple sequence repeat (SSR) anchored polymerase chain reaction amplification. Genomics 20: 176-183.

(Manuscript received on 1 November 2006; revised on 12 November 2006) 